\title{
Relative importance of the trophic and direct pathways on PCB contamination in the rotifer species Brachionus calyciflorus (Pallas)
}

\author{
C. Joaquim-Justo ${ }^{1}$, V. Gosselain ${ }^{2}$, J. P. Descy ${ }^{2} \&$ J. P. Thomé ${ }^{1}$ \\ ${ }^{1}$ University of Liège, Institute of Zoology, Quai Van Beneden 22, 4020 Liège, Belgium \\ ${ }^{2}$ F.U.N.D.P., rue de Bruxelles 61, 5000 Namur, Belgium
}

Key words: PCB, rotifer, trophic pathway, Direct pathway, Meuse

\begin{abstract}
To determine the contribution of food ingestion (trophic pathway) to PCB contamination of zooplankton in the river Meuse (Belgium), we used ${ }^{14} \mathrm{C}$-labelled algae (Dictyosphaerium ehrenbergianum) to measure ingestion and assimilation rates in the rotifer species Brachionus calyciflorus. When the concentration of algae in the culture medium varied from $2010^{3}$ to $20010^{3}$ algal cells $\mathrm{ml}^{-1}\left(0.12\right.$ to $\left.1.18 \mathrm{mg} \mathrm{Cl}^{-1}\right)$, the Brachionus calyciflorus ingestion rate varied from $0.25 \pm 0.12$ to $1.52 \pm 0.43 \mathrm{ng} \mathrm{C}$ ind $^{-1} \mathrm{~h}^{-1}$ at $15{ }^{\circ} \mathrm{C}$ and from $0.74 \pm 0.17$ to $5.93 \pm 0.61 \mathrm{ng} \mathrm{C}$ ind $^{-1} \mathrm{~h}^{-1}$ at $20^{\circ} \mathrm{C}$. The assimilation efficiency (ratio of the assimilation rate to the ingestion rate) measured in a culture medium containing $20010^{3}$ algal cells $\mathrm{ml}^{-1}$ was $55.7 \pm 5.8 \%$. Since the PCB concentration measured in the phytoplankton of the river Meuse is about $3 \mu \mathrm{g} \mathrm{PCBs}^{-1} \mathrm{D}$.W., the estimated PCB contamination of zooplankton ascribable to the trophic pathway ranges from $0.22 \pm 0.17$ to $1.31 \pm 0.77 \mu \mathrm{g} \mathrm{PCBs} \mathrm{g}{ }^{-1} \mathrm{D}$.W. at $15{ }^{\circ} \mathrm{C}$ and from $0.64 \pm 0.34$ to $5.10 \pm 2.10 \mu \mathrm{g} \mathrm{PCBs} \mathrm{g}{ }^{-1} \mathrm{D}$.W. at $20^{\circ} \mathrm{C}$. The lower figure based on measurements effected at $20^{\circ} \mathrm{C}$ is comparable to the actual level measured in zooplankton samples collected in the river Meuse $(0.69 \pm 0.20 \mu \mathrm{g}$ PCBs $\mathrm{g}^{-1}$ D.W.). The applicability of the formula used in our estimate was checked in a 48-hour in vitro experiment in which the rotifers were fed contaminated algae. The PCB accumulation measured in the rotifers was found to coincide with the calculated PCB contamination. Additional experiments were carried out to determine the contribution of the direct pathway to PCB contamination of zooplankton living in the river Meuse $(0.02 \mu \mathrm{g}$ PCBs $1^{-1}$ of water; average dissolved organic matter: $3 \mathrm{mg} \mathrm{Cl}^{-1}$ ). The $\mathrm{PCB}$ concentration in zooplankton resulting from direct uptake of PCBs from the water was estimated at $0.19 \pm 0.05 \mu \mathrm{gCBs}^{-1} \mathrm{D}$.W. These results show that in zooplankton living in polluted ecosystems, $\mathrm{PCBs}$ are likely to accumulate via the trophic pathway to concentrations up to 30 times higher than by direct contamination. Furthermore, our estimates of PCB contamination via the trophic pathway coincide quite well with actual concentrations measured in situ.
\end{abstract}

\section{Introduction}

Polychlorinated biphenyls (PCBs) are widespread micropollutants whose presence has been reported not only in the aquatic ecosystems of industrially developed regions (Henry et al., 1989; Taylor et al., 1991; Sanders et al., 1992), but also in those of desert and remote places such as the Antarctic oceans (Joiris \& Overloop, 1991). These lipophilic compounds are highly resistant to any biodegradation process and are thus abundantly accumulated in aquatic organisms.
PCB contamination of zooplanktonic organisms occurs mainly either by direct uptake through exchange surfaces or by ingestion of contaminated food (the indirect pathway). There is controversy as to the relative importance of each pathway in PCB contamination of zooplankton.

For some investigators, the main mechanism of PCB contamination of zooplankton is direct partitioning of PCBs from the water to the internal lipid pools of zooplanktonic organisms (Clayton et al., 1977 and Linko et al., 1979). Others (Risebrough et al., 1972 and Scura \& Theilacker, 1977) have suggested that 
PCBs accumulated via the trophic pathway would be released into the environment by excretion or partitioning processes whenever the organisms reach their equilibrium level of PCB contamination. Hiraizurni et al. (1979), moreover, found a rather good correlation between the PCB concentration factor and the specific surface area of plankton samples. This led them to hypothesize that the PCB concentration factor of plankton is controlled mainly by the organisms' specific surface area and secondly by their organic content. Delbeke et al. (1990), on the other hand, finding no correlation between PCB load and the lipid content of marine zooplankton, concluded that PCB concentrations measured in zooplankton result from intake through ingestion of food, apparent loss by biological dilution, and true elimination.

The aim of the study reported in this paper is to establish the relative contribution of the direct and indirect pathways to $\mathrm{PCB}$ contamination of zooplankton living in the river Meuse (Belgium).

\section{Materials and methods}

\section{Culture methods}

The rotifers were grown in Volvic water at $23 \pm 2{ }^{\circ} \mathrm{C}$ and fed centrifuged aliquots of a dense culture of Dictyosphaerium ehrenbergianum $\left(610^{5}\right.$ cells $\mathrm{ml}^{-1}$ in Volvic water) They were subjected to a light cycle of 16 hours of illumination and 8 hours of darkness. The algae were cultured in a medium described by Schlösser (1982) (S-medium) under light and temperature conditions identical to those used for the rotifers. The cultures were constantly aerated with sterile air and magnetically stirred.

\section{Investigation of the trophic pathway}

To estimate the contribution of the trophic pathway, we measured ingestion and assimilation rates in the rotifer Brachionus calyciflorus. This rotifer is an abundant, if not the most abundant species in the river Meuse (Marneffe \& Thomé, 1991) A green algae present in the Meuse (Descy, 1987), Dictyosphaerium ehrenbergianum, was used as food for the rotifer during the experiments.

Ingestion rate measurements were based on the radiotracer technique. A culture of Dictyosphaerium ehrenbergianum $(500 \mathrm{ml})$ in exponential phase was added $250 \mu \mathrm{Ci}$ of $\mathrm{Na} \mathrm{H}^{14} \mathrm{CO}_{3}$ and grown under conditions described in the culture methods. After 48 hours of labelling, i.e. after 3.5 generations, adequate aliquots of the culture were sampled and washed by three successive centrifugations and resuspensions in Volvic water. Five hundred rotifers acclimated to the specific environmental conditions of each experiment were placed in $50 \mathrm{ml}$ of Volvic water containing from $2010^{3}$ to $20010^{3}{ }^{14} \mathrm{C}$-labelled algae $\mathrm{ml}^{-1}$ (i.e. from 0.12 to $1.18 \mathrm{mg} \mathrm{C}^{-1}$ ) at $20^{\circ} \mathrm{C}$ (first set of experiments) or $15^{\circ} \mathrm{C}$ (second set). The rotifers were allowed to feed for 15 minutes, less than the minimal gutpassage time of Brachionus calyciflorus according to Starkweather \& Gilbert (1977) (also appropriate when B. calyciflorus is feeding on < Dictyosphaerium ehrenbergianum; Marneffe, pers. commun.). After the feeding period, the animals were collected on a $63 \mu \mathrm{m}$ mesh plankton net, narcotized for $2 \mathrm{~min}$ in a bath of $\mathrm{CO}_{2}$-enriched water and killed by addition of $250 \mu \mathrm{l}$ of a $40 \%$ formaldehyde solution. The rotifers were resuspended in Volvic water and three cohorts of 30 individuals were transferred through two successive baths of Volvic water under a dissecting microscope before being placed in scintillation vials. Each cohort received $500 \mu \mathrm{l}$ of Protosol (Dupont de Nemours) and was incubated for 2 hours at $45^{\circ} \mathrm{C}$. Then, $300 \mu 1$ of glacial acetic acid and $4.5 \mathrm{ml}$ of scintillation cocktail (Beckman, Ready Safe) were poured into the vials and the radioactivity was measured with a liquid scintillation counter (Beckman LS 600).

As ingestion rates were measured over short periods (15 minutes), the existence of a nycthemeral cycle in the feeding activity of the animals could have led us to over- or underestimate the ingestion rate. We therefore monitored the feeding activity of the rotifers over a whole nycthemeron to check for variations of the ingestion rate. An aliquot of centrifuged Dictyosphaerium ehrenbergianum culture sufficient to give a final cell density of $1210^{5}$ cells $\mathrm{ml}^{-1}$ was added to 1.51 Volvic water containing 10 rotifers $\mathrm{ml}^{-1}$. A procedural blank without rotifers enabled us to monitor algal growth. Both vessels were subjected to conditions described here above for the culture of algae. The algae were counted with a Bürker cell at 3-hour intervals over 24 hours.

Assimilation rate measurements differed in only two respects from the procedure followed for ingestion rate measurements:

- the feeding time was about 6 hours instead of 15 minutes;

- before the rotifers were killed, they were allowed to feed for 30 minutes on unlabelled algae to enable them to empty their guts of labelled algae. All mea- 
surements were effected in the presence of $20010^{3}$ cells $\mathrm{ml}^{-1}$. Nielsen \& Olsen (1989) emphasized the importance of using uniformly labelled algae in assimilation rate measurements. They demonstrated that Scenedesmus acutus was uniformly labelled after 8 generations. Nevertheless, the assimilation efficiency of Daphnia magna fed with S. acutus labelled for 3.5 or 8 generations only differed by $5 \%$. Moreover, after a labelling period of 3.5 generations, $92 \%$ of the algal biomass in the $D$. ehrenbergianum has been newly produced. So we considered that our labelling procedure was suitable for assimilation efficiency measurements.

One can logically assume that the amount of PCBs accumulated by the rotifers is partly eliminated by excretion, metabolization, or diffusion, so the PCB concentration measured in natural zooplankton should be the result of input phenomena on the one hand and of these "elimination" processes on the other. Consequently, in order to estimate amounts of PCBs accumulated by the trophic pathway, we had also to determine the elimination rate. Rotifers contaminated to a concentration of $11 \mu \mathrm{g}$ Aroclor $1260 \mathrm{~g}^{-1}$ D.W. were placed in 11 of PCB-free Volvic water containing 6 $10^{5}$ uncontaminated algae per $\mathrm{ml}$. This PCB mixture was chosen for experimentation because its composition corresponds quite well with the mixture of PCBs detected in natural plankton. After a 24-hour incubation period at room temperature, the rotifers were collected on a $63 \mu \mathrm{m}$ mesh plankton net and analysed for PCBs.

An indirect contamination of the rotifers was carried out in the laboratory to compare in vitro contamination of the rotifers with an estimation of indirect contamination based on the ingestion and assimilation rate measurements and the estimate of the PCB 'elimination' rate of the rotifers. The algae were contaminated in a chemostat where a constant flux $\left(300 \mu \mathrm{l} \mathrm{min}^{-1}\right)$ of PCB-enriched S-medium (5 $\mu \mathrm{g}$ Aroclor 1260 as a methanol solution added per liter of medium) was maintained. One liter of PCB-free Volvic water containing 50 rotifers $\mathrm{ml}^{-1}$ received $610^{5}$ cells ml ${ }^{-1}$ of contaminated algae (mean contamination: $25 \mu \mathrm{g}$ Aroclor $1260 \mathrm{~g}^{-1}$ D.W.). The experimental glass vessels were hermetically closed and no air was bubbled through the vessels.

We further measured the PCB concentration in natural phytoplankton and zooplankton collected in the river Meuse so as to calculate the amount of PCBs ingested in situ with the food. Zooplankton samples were collected by towing a conical $81 \mu \mathrm{m}$ mesh plank- ton net. Water sampled from the river Meuse was filtered through a $63 \mu \mathrm{m}$ mesh plankton net to remove the zooplanktonic organisms from the water. Suspended matter (essentially phytoplankton) was collected on a $1.2 \mu \mathrm{m}$ Whatman GF/C filter. The filtered water was analysed for PCBs.

\section{Investigation of the direct pathway}

To investigate the direct pathway, we conducted in vitro experiments where the rotifers were exposed to a range of concentrations of Aroclor 1260 added to the culture medium. One hundred thousand rotifers were placed in 1.51 of Volvic water containing PCB concentrations varying from 0.06 to $3 \mu \mathrm{g}$ of Aroclor $126 \mathrm{l}^{-1}$. The glass vessels containing the contaminated water were hermetically closed and placed on a magnetic stirrer. Since humic compounds have been shown to reduce the bioconcentration of PCBs in aquatic organisms from contaminated waters (Carlberg et al., 1986), the influence of such compounds on direct accumulation was also studied. So at the two lowest PCB concentrations, the experiments were repeated with Volvic water containing $3 \mathrm{mg} \mathrm{C}$ of humic acid per liter; this is the average concentration of organic matter generally present in Meuse water. After a 24-hour incubation at room temperature, the rotifers were collected on a $63 \mu \mathrm{m}$ mesh plankton net and analysed for PCBs.

\section{PCB analysis procedure}

All solvents (hexane, acetone) were of HPLC and/or Pesticide grade and were purchased from ALLTECH (Deerfield, USA). Analytical standard grade Aroclor 1260 , op'DDE used as an internal standard, and pure PCB congeners used for Aroclor 1260 quantitation (IUPAC ${ }^{\circ} 44,52,70,87,101,118,136,138,149$, $153,156,170,180$ and 183) were obtained from PROMOCHEM GmbH (Wessel, Germany).

Prior to PCB extraction the solid samples were freeze-dried. These dry samples (rotifers and algae) were homogenized for 1 hour in $5 \mathrm{ml}$ of hexaneacetone $(1: 1 ; \mathrm{V}: \mathrm{V})$ with a Vortex homogenizer. After centrifugation at $1750 \mathrm{~g}$ for $15 \mathrm{~min}$, the resulting pellet was treated similarly with $5 \mathrm{ml}$ hexane-acetone mixture. The supernatants from both centrifugations were pooled and evaporated (never to dryness) under a gentle nitrogen stream. The hexane-acetone mixture was replaced by $n$-hexane up to a final volume of $1 \mathrm{ml}$. A procedural blank was performed without a sample. The extraction efficiency was tested by adding a known 
Table 1. Assimilation rate of Brachionus calyciflorus grazing on Dictyosphaerium ehrenbergianum.

\begin{tabular}{lllllll}
\hline & $\begin{array}{l}\text { Time in } \\
\text { labelled } \\
\text { food }\end{array}$ & $\begin{array}{l}\text { Time in } \\
\text { unlabelled } \\
\text { food }\end{array}$ & $\begin{array}{l}\text { Assimilated } \\
{ }^{14} \mathrm{C} \\
(\mathrm{ng} \mathrm{C} \text { ind }\end{array}$ & $\begin{array}{l}\text { Measured } \\
\text { "assimilation } \\
\text { rate" } \\
\left(\mathrm{ng} \mathrm{C} \mathrm{ind}{ }^{-1} \mathrm{~h}^{-1}\right)\end{array}$ & $\begin{array}{l}\text { Calculated } \\
\text { assimilation rate } \\
\left(\mathrm{ng} \mathrm{C} \text { ind }^{-1} \mathrm{~h}^{-1}\right)\end{array}$ & $\begin{array}{l}\text { Assimilation } \\
\text { efficiency }\end{array}$ \\
\hline Experiment 1 & 5 hours & 30 minutes & 29.5 & 5.9 & 8.1 & $49 \%$ \\
Experiment 2 & 5.5 hours & 30 minutes & 42.4 & 7.7 & 9.9 & $59 \%$ \\
Experiment 3 & 5.5 hours & 16.5 hours & 10.4 & 1.9 & 9.9 & $59 \%$ \\
Average & - & - & - & $5.2 \pm 3.0$ & $9.3 \pm 1.0$ & $55.7 \pm 5.8 \%$ \\
\hline
\end{tabular}

$(-)$ : meaningless

amount of op'DDE (a DDT metabolite never found in samples analysed) to the sample prior to extraction.

This hexane extract was cleaned by beeing vigorously shaken for $2 \mathrm{~min}$ with a Vortex homogenizer in the presence of $2 \mathrm{ml}$ of $\mathrm{H}_{2} \mathrm{SO}_{4}$ (a mixture of $\mathrm{H}_{2} \mathrm{SO}_{4}$ fuming $30 \% \mathrm{SO}_{3}$ and $\left.95 \% \mathrm{H}_{2} \mathrm{SO}_{4}, 1: 4 ; \mathrm{V}: \mathrm{V}\right)$. The organic layer was removed and saved and the acid phase again shaken with $2 \mathrm{ml}$ hexane. Both organic layers were centrifuged at $1750 \mathrm{~g}$ for $4 \mathrm{~min}$ and the supernatants pooled. After concentration of the sample to a final volume of $1 \mathrm{ml}$ under a gentle stream of nitrogen, a second clean-up step was performed as described in Thomé et al. (1987), with Florisil solid phase extraction cartridges (Envi-Florisil, Supelco, Bellefonte, USA).

Extraction of liquid samples was performed by SPE (solid phase enrichment) with $\mathrm{C}_{18}$ cartridges (Envi-18, Supelco, Bellefonte, USA) as described by Thomé \& Vandaele (1987).

Samples were analysed with a Carlo-Erba Fractovap 5160 gas chromatograph equipped with a ${ }^{63} \mathrm{Ni}$ ECD. The PCBs were separated on a $30 \mathrm{~m} \times 0.32 \mathrm{~mm}$ fused silica column coated with $0.2 \mu \mathrm{m}$ of immobilized DB-5 liquid phase (J \& W, USA). Carrier gas was hydrogen at an inlet pressure of $510^{4} \mathrm{~Pa}\left(2 \mathrm{ml} \mathrm{min}^{-1}\right)$; make-up gas was $\mathrm{Ar} / \mathrm{CH}_{4}(90: 10)$ at a flow rate of $30 \mathrm{ml}$ $\min ^{-1}$; injector temperature was $260^{\circ} \mathrm{C}$ and detector temperature was $300^{\circ} \mathrm{C}$. The gas chromatograph was equipped with a Carlo-Erba As-V 570 automatic liquid sampler used with a split-splitless vaporizing injector. Samples were injected in the splitless mode (hold time $=45 \mathrm{~s}$ ) from $60^{\circ} \mathrm{C}$ to $260^{\circ} \mathrm{C}$ at $4{ }^{\circ} \mathrm{C} \mathrm{min}^{-1}$ (final hold $=10 \mathrm{~min}$ ).

The PCB peak heights were integrated with an LDC Milton Roy electronic integrator (Shannon Airport Co. Clare, Ireland). The individual PCB congeners were identified by their retention times. The concentrations of the 14 pure PCB congeners were calculated from the added amount of internal op'DDE standard. The total PCB concentration, expressed in Aroclor 1260 equivalents, was calculated by taking into account the contribution of these PCB congeners to the total weight of the Aroclor 1260 standard mixture (i.e. $49 \%$ ).

\section{Results}

Investigation of the trophic pathway

A regular decrease in food concentration was observed throughout the nycthemeron in the experimental vessel containing the rotifers. This means that under our experimental conditions, Brachionus calyciflorus feeds continuously. The ingestion rate measurements could thus be performed at any time of the day.

As expected, the rotifers' ingestion rate increased with increasing food supply (Figs 1 and 2). The rate ranged from $0.25 \pm 0.12$ to $1.52 \pm 0.43 \mathrm{ng} \mathrm{C}$ ind $^{-1}$ $\mathrm{h}^{-1}$ at $15^{\circ} \mathrm{C}$ and from $0.74 \pm 0.17$ to $5.93 \pm 0.61 \mathrm{ng}$ $\mathrm{C}$ ind ${ }^{-1} \mathrm{~h}^{-1}$ at $20^{\circ} \mathrm{C}$ for food concentrations between 0.12 and $1.18 \mathrm{mg} \mathrm{C} \mathrm{I}^{-1}$.

The exact incubation times and the results of the assimilation rate measurements are reported in Table 1. A comparison of the assimilation rates measured in experiments 2 and 3 suggests that respiration of assimilated ${ }^{14} \mathrm{C}$ begins within a few hours. This implies that the assimilation rate measurements were underestimated. We therefore corrected the measured rates as follows. Comparing experiments 2 and 3 , we infer that in 16 hours a rotifer loses $42.4-10.4=32 \mathrm{ng}$ of assimilated carbon. The hourly loss is thus $2 \mathrm{ng} \mathrm{C}$ ind $^{-1}$ $\mathrm{h}^{-1}$. Since experiment 1 lasted 5.5 hours, the loss over this period should be $5.5 \times 2=11 \mathrm{ng} \mathrm{C}$. The amount of carbon assimilated by a rotifer in 5 hours (time 
Ingestion rate (ng C.ind.$^{-1} \mathrm{~h}^{-1}$ )

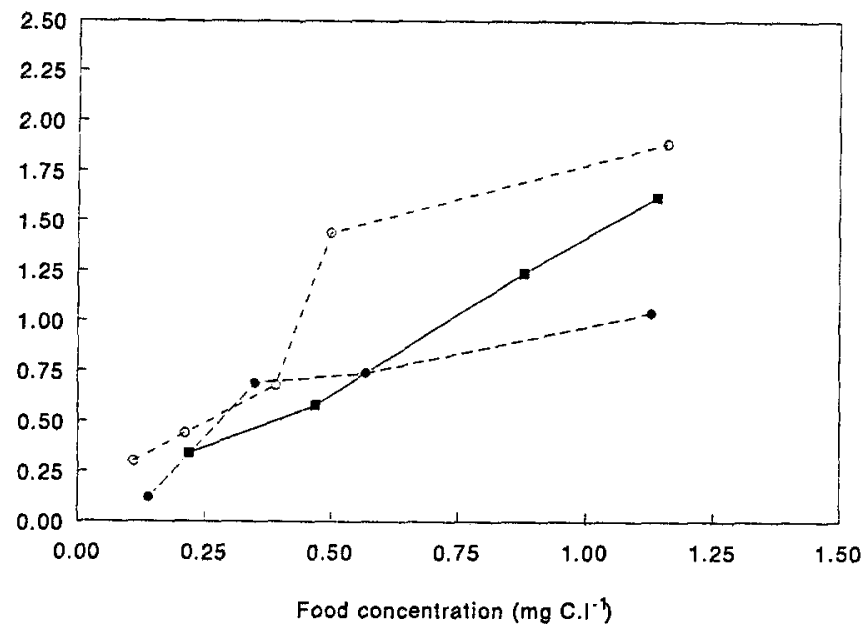

Fig. 1. Ingestion rate of Brachionus calyciflorus at $15^{\circ} \mathrm{C}$. The different curves are replicates.

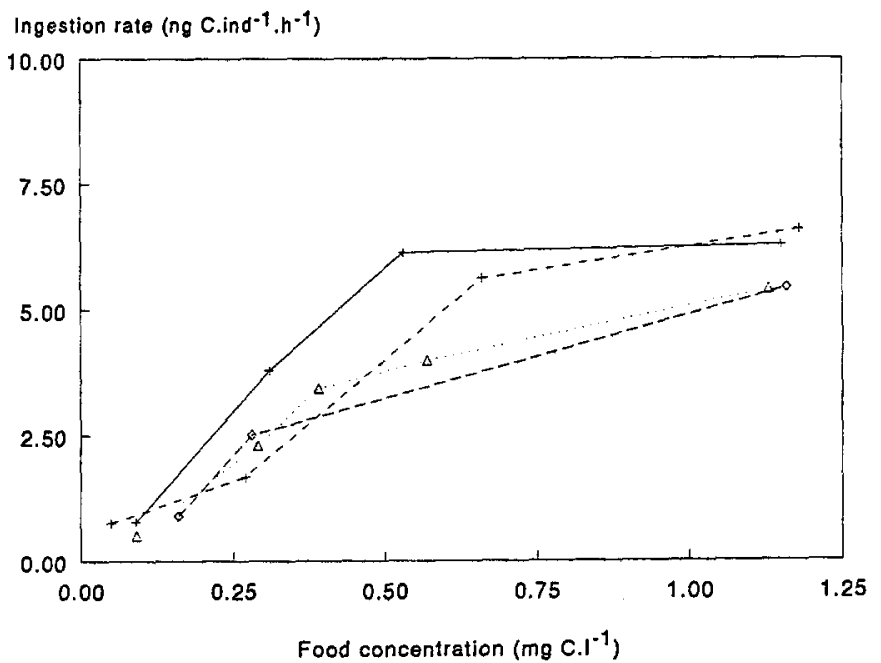

Fig. 2. Ingestion rate of Brachionus calyciflorus at $20^{\circ} \mathrm{C}$. The different curves are replicates.

spent in labelled food) is thus $29.5+11=40.5 \mathrm{ng} \mathrm{C}$. Hence, the corrected assimilation rate is $\frac{40.5}{5}=8.1 \mathrm{ng} \mathrm{C}$ ind $^{-1} \mathrm{~h}^{-1}$. The assimilation efficiency (ratio between the assimilation rate versus the ingestion rate) is of $55.7 \pm 5.8 \%$.

The PCB concentration measured in the rotifers after the decontamination period (24 hours) was $3.4 \mu \mathrm{g}$ PCBs $g^{-1}$ D.W., amounting to $30 \%$ of their initial PCB content. It was impossible, however, to determine whether this diminution of the contamination level of the animals was due to some elimination process or to metabolic transformation of the PCBs. In the former case, the concentration of PCBs rejected into the medium would be below the detection threshold (i.e. $0.2 \mathrm{ng} \mathrm{PCBs} 1^{-1}$ ); in the latter case, the newly formed molecules would most probably be undetected by the analytical method used in this study.

\section{Indirect contamination experiment}

Figure 3 shows the level of PCB accumulation by the algae used in the indirect contamination of Brachionus calyciflorus. After 5 days, the PCB concentration in the algae reaches a fairly stable, maximal value of about $25 \mu \mathrm{g} \mathrm{PCBs} \mathrm{g}^{-1} \mathrm{D}$.W.

PCB accumulation by the rotifers via the trophic pathway appears to be progressive (see Table 2). By comparison with the high PCB levels in the food, the PCB concentrations accumulated by the rotifers seem rather low. 


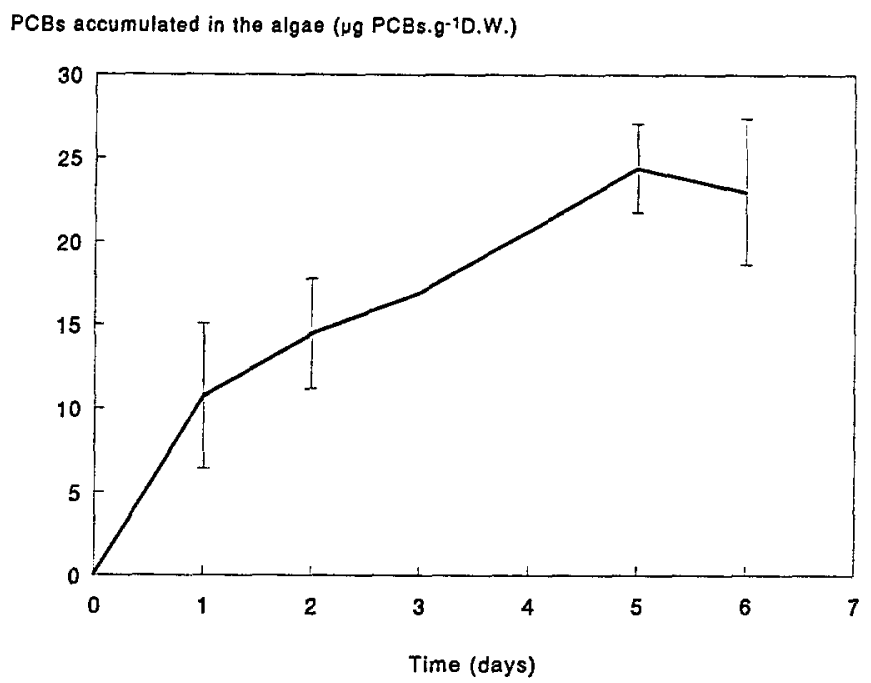

Fig. 3. PCB accumulation of the algae Dictyosphaerium ehrenbergianum (5 $\mu \mathrm{g}$ Aroclor $1260 \mathrm{1}^{-1}$ of culture medium).

Table 2. In vitro contamination of the rotifers by the trophic pathway.

\begin{tabular}{|c|c|c|c|}
\hline $\begin{array}{l}\text { Time of feeding on contaminated food } \\
\text { (hours) }\end{array}$ & $\mathrm{T}_{0}$ & $\mathbf{T}_{24}$ & $T_{48}$ \\
\hline 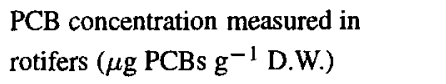 & $<$ d.t. $*$ & 2.6 & 4.2 \\
\hline $\begin{array}{l}\text { Calculated PCB concentration in } \\
\text { rotifers ( } \mu \mathrm{g} \mathrm{PCBs} \mathrm{g}^{-1} \mathrm{D} . \mathrm{W} \text {.) }\end{array}$ & 0 & 3.4 & 6.8 \\
\hline $\begin{array}{l}\text { PCB concentration in food (algae) } \\
\left(\mu \mathrm{g} \text { PCBs } \mathrm{g}^{-1} \mathrm{D} . \mathrm{W} .\right)\end{array}$ & 23.0 & 25.3 & 27.0 \\
\hline $\begin{array}{l}\text { Food density } \\
\left(\text { algal cells } \mathrm{ml}^{-1}\right)\end{array}$ & $610^{5}$ & $3.510^{5}$ & $3.510^{5}$ \\
\hline
\end{tabular}

* d.t.: detection threshold.

To calculate PCB contamination via the trophic pathway, we introduced the data presented above into the following equation:

$$
\begin{gathered}
\frac{I \times A \times[\mathrm{PCBs}]_{\text {frod }} \times 24(\mathrm{~h}) \times(1-E) \times \text { average age }(\mathrm{d})}{\text { Dry weight of } B . \text { calyciflorus }} \\
=\text { estimated }[\mathrm{PCB}]_{\text {zoo. }- \text { indir. }}
\end{gathered}
$$

$\mathbf{I}=$ ingestion rate $\left(\mathrm{g} \mathrm{D} . \mathrm{W}\right.$ ind $\left.{ }^{-1} \mathrm{~h}^{-1}\right)$

$\mathbf{A}=$ assimilation efficiency (\%)

$\mathbf{E}=$ elimination rate $(\%)$.

$[\mathrm{PCB}]_{\text {food }}$ expressed as $\mu \mathrm{g} \mathrm{g}^{-1}$ D.W.

Dry weight of $B$. calyciflorus $=15.110^{-8} \mathrm{~g}$

Dry weight of $D$. ehrenbergianum $=11.810^{-12} \mathrm{~g}(5.9$ $\left.10^{-12} \mathrm{~g} \mathrm{C}\right)$
The applicability of Equation 1 to this experimental situation was tested. Mean ingestion rate of $B$. calyciflorus during the experiment was calculated to be of 5203 algal cells ind ${ }^{-1} \mathrm{~d}^{-1}$ i.e. $1.310^{-7} \mathrm{~g}_{\text {ind }}{ }^{-1} \mathrm{~d}^{-1}$ on the basis of the data presented in Table 3. Considering that the mean contamination of the algae used as food was $24 \mu \mathrm{g} \mathrm{PCBs}^{-1} \mathrm{D}$.W., equation 1 yields:

$$
\begin{gathered}
\frac{1.310^{-7} \times 56 \% \times 24 \times 30 \% \times 2}{15.110^{-8}} \\
=6.9 \mu \mathrm{gPCBs} \mathrm{g}^{-1} \mathrm{D} . \mathrm{W} .
\end{gathered}
$$

This calculated value is close to the measured value (4.2 $\mu \mathrm{g} \mathrm{PCBs}^{-1}$ D.W.; see Table 2) and thus validates Equation 1. The slight overestimation provided by equation 1 may come from an unsuitability of the assimilation efficiency considered. Indeed, it has been proved that the assimilation efficiency of rotifers decreases with increasing availability of food (Liemeroth, 1980, Pilarska, 1977), however our measurements were carried out in the presence of $210^{5}$ algal cells $\mathrm{ml}^{-1}$ instead of $610^{5}$ algal cells $\mathrm{ml}^{-1}$. Moreover, the PCB assimilation efficiency probably differs from gross carbon assimilation efficiency; so complementary experiments should be carried out to provide more information concerning this point.

\section{$P C B$ contamination of different compartments of the river Meuse (Belgium)}

Table 3 shows the PCB concentrations measured in different compartments of the river Meuse in 1993 in the vicinity of Liège (downstream from the industrial basin 
Table 3. Mean PCB contamination of different compartments of the river Meuse (Belgium) downstream from the industrial basin of Liège (mean values for 2 sampling stations).

\begin{tabular}{llll}
\hline & $\begin{array}{l}\text { Water } \\
\left(\mathrm{ng} \mathrm{PCBs}{ }^{-1}\right)\end{array}$ & $\begin{array}{l}\text { Suspended matter } \\
\left(\mu \mathrm{g} \mathrm{PCBs} \mathrm{g}^{-1} \mathrm{D} . \mathrm{W} .\right)\end{array}$ & $\begin{array}{l}\text { Zooplankton } \\
\left(\mu \mathrm{g} \mathrm{PCBs} \mathrm{g}^{-1} \mathrm{D} . \mathrm{W} .\right)\end{array}$ \\
\hline 21-04-93: & 19.20 & 3.70 & 0.59 \\
27-05-93: & 22.80 & - & 0.80 \\
30-06-93: & 26.00 & 2.78 & - \\
Average & $21.80 \pm 3.40$ & $3.24 \pm 0.65$ & $0.69 \pm 0.20$ \\
contamination & & & \\
\hline
\end{tabular}

(-): not available.

Table 4. Contamination of the rotifers by the direct pathway.

\begin{tabular}{|c|c|c|c|c|c|}
\hline & $\begin{array}{l}\text { PCB concentration in the } \\
\text { medium } \\
\left(\mu \mathrm{g} \text { Arocior } 1260^{-1}\right)\end{array}$ & 3 & 0.6 & 0.06 & \\
\hline \multirow[t]{2}{*}{$\begin{array}{l}\text { Medium free } \\
\text { of humic acid. }\end{array}$} & $\begin{array}{l}\mathrm{PCB} \text { contamination of the } \\
\text { rotifers } \\
\left(\mu \mathrm{g} \text { Aroclor } 1260 \mathrm{~g}^{-1} \text { D.W.) }\right.\end{array}$ & 40 & 9 & 1 & \\
\hline & Bioconcentration factor & $1310^{3}$ & $1510^{3}$ & $1710^{3}$ & Mean: $1510^{3} \pm 1.710^{3}$ \\
\hline \multirow{2}{*}{$\begin{array}{l}\text { Medium } \\
\text { containing } \\
3 \mathrm{mgC}^{-1} \text { of } \\
\text { humic acid. }\end{array}$} & $\begin{array}{l}\text { PCB contamination of the } \\
\text { rotifers } \\
\text { ( } \mu \mathrm{g} \text { Aroclor } 1260 \mathrm{~g}^{-1} \text { D.W.) }\end{array}$ & - & 5 & 0.57 & \\
\hline & Bioconcentration factor & - & $810^{3}$ & $9.510^{3}$ & Mean: $8.910^{3} \pm 0.810^{3}$ \\
\hline
\end{tabular}

and the municipal sewage discharge; for a detailed description of the area studied see Marneffe $e t$ al. in press). These results are in good agreement with those of Marneffe \& Thomé (1991). The contamination of phytoplankton (suspended matter) is considerable, although due solely to direct uptake from water (bioconcentration factor: 142731) and is higher than that of zooplanktonic organisms (30837), although these are belonging to higher trophic levels.

\section{Estimate of $P C B$ contamination in natural zooplankton via the trophic pathway}

Resolution of equation 1 yields the estimated PCB concentration that zooplankton accumulate exclusively via the trophic pathway. The estimated PCB contamination of zooplankton varies from $0.22 \pm 0.17$ to $1.31 \pm 0.77 \mu \mathrm{g}$ PCBs $\mathrm{g}^{-1}$ D.W. when calculated from the ingestion rates measured at $15{ }^{\circ} \mathrm{C}$ and from
$0.64 \pm 0.34$ to $5.10 \pm 2.10 \mu \mathrm{g}^{\mathrm{PCBs}} \mathrm{g}^{-1} \mathrm{D}$.W. for ingestion rates measured at $20^{\circ} \mathrm{C}$.

\section{Direct contamination}

The results of the direct contamination experiments are presented in Table 4 . There is a near-linear relation between the PCB concentration accumulated by the animals directly from the water and the PCB concentration in the water. The presence of humic acid in the medium decreases by half the amount of xenobiotic accumulated. This is not surprising, since humic compounds display chemical affinity for PCBs (Jota \& Hasset, 1991; Thomé et al., in press). Consequently, addition of humic acid to the experimental medium decreases the amount of PCB liable to accumulate in the rotifers. 
Estimate of $P C B$ contamination of the zooplankton via the direct pathway

To estimate the PCB concentration that natural zooplankton would accumulate exclusively via the direct pathway, we introduced the above data into Equation 2.

$\mathrm{BCF} \times[\mathrm{PCB}]$ in the water of the river Meuse

$$
=\text { estimated }[\mathrm{PCB}]_{\mathrm{zoo} .-\mathrm{dir}} \text {. }
$$

BCF : Experimental bioconcentration factor

Since direct uptake of PCBs appears to be almost linearly related to the PCB concentration in the water (Table 4), the contamination of natural zooplankton by this pathway can be estimated by multiplying the $\mathrm{PCB}$ concentration in river Meuse water by the rotifer bioconcentration factor in the experimental medium (i.e. the ratio of the PCB concentration in the rotifers to the PCB concentration in the experimental medium). As river water contains humic compounds, we considered only the data from experiments in which humic acid was added to the water. Equation 2 yields a value of about $0.19 \pm 0.05 \mu \mathrm{g} \mathrm{PCBs}^{-1} \mathrm{D}$.W. for direct contamination of natural zooplankton in the river Meuse.

\section{Discussion}

Our estimate of PCB concentrations accumulated in zooplankton by ingestion of contaminated food ranges from values close to those actually measured in the environment to values up to 30 times higher. The considerable difference between minimal and maximal estimates of indirect contamination is essentially due to the wide range of ingestion rates. It is difficult to compare our ingestion rate measurements with others found in the literature because other workers did not use the same species of algae as food. Nevertheless, our results often tally with results obtained with cells of comparable size (equivalent spherical diameter of about $3.5 \mu \mathrm{m}$ ). For example, Bogdan \& Gilbert (1982) using Rhodotorula glutinis measured a clearance rate of 1.17 to $3.02 \mu \mathrm{lind}^{-1} \mathrm{~h}^{-1}$ under conditions where we obtained a clearance rate of $4.87 \pm 1.3 \mu l$ ind $^{-1} \mathrm{~h}^{-1}$. Haney et al. (1986) using the same food measured a clearance rate of $4.4 \mu \mathrm{l}$ ind ${ }^{-1} \mathrm{~h}^{-1}$ under conditions where we observed a clearance rate of $3.7 \pm 1 \mu \mathrm{l}$ ind ${ }^{-1} \mathrm{~h}^{-1}$. We may therefore assert that our ingestion rate measurements corroborate those of other authors using comparable conditions.

As has been abundantly proved, ingestion rate measurements are tightly related to the experimental conditions (temperature, quantity of food available, etc.). Therefore, the closer the experimental conditions are to those encountered in situ, the closer the ingestion rate measured will be to the in situ ingestion rate of the rotifers and the more accurate will be our estimate of PCB contamination of zooplankton. So how well do our conditions reflect the real ones? In the river Meuse, the temperature circles around $20^{\circ} \mathrm{C}$ during late spring and summer (Gosselain et al., 1994). Furthermore, a concentration of $1.18 \mathrm{mg}$ of algal carbon per liter of water is in the range of maximal value of phytoplankton biomass (Descy \& Gosselain, 1994). Finally, one should take into account the fact that some of the algal species which contribute to this biomass are inedible or barely edible by rotifers. Consequently, the best estimate of PCB contamination of the zooplankton by the trophic pathway should be that based on ingestion rate measurements carried out at $20^{\circ} \mathrm{C}$ and with low concentrations of food. These estimates exactly match the PCB concentrations measured in situ $(0.64 \pm 0.34$ for the estimated value and $0.69 \pm 0.20$ for the measured value). This suggests that Equation 1 is indeed appropriate for estimating PCB contamination of natural zooplankton via the indirect pathway. Application of Equation 1 to the in vitro experiment further corroborates this assertion (see Table 2).

As for PCB contamination via the direct pathway, our estimate is lower than the real value. This implies that this mechanism of contamination is not quantitatively important unlike contamination through trophic pathway. Hiraizumi et al. (1979) measured a bioconcentration factor of about 1000 for dehydrated zooplankton placed in PCB-enriched sea water. The divergence between their results and ours probably comes from differences in experimental procedures (size of the zooplankton, composition of the medium, PCB solution, etc.). Their results do suggest, nevertheless, that the bioconcentration factor measured in our experiments is not underestimated.

Further evidence of the greater contribution of the trophic pathway is given by the comparison between our own estimates of PCB accumulation via the two pathways: there is a factor of up to 30 between the two estimates, in favour of PCB accumulation by ingestion of contaminated food.

Taken together, the results presented here lead us to the conclusion that in natural polluted ecosystems, 
indirect uptake through ingestion of contaminated food is the predominant pathway for PCB accumulation in zooplankton.

\section{Acknowledgments}

The study presented here was supported by the FRFC (Fonds de la Recherche Fondamentale Collective, Belgium) through two grant agreements ( ${ }^{\circ} 2.4539 .91$ and $n{ }^{\circ} 2.4545 .94$ ) and by the IRSIA (Institut pour l'Encouragement de la Recherche Scientifique dans l'Industrie et l'Agriculture, Belgium) through a research grant. The authors are indebted to Mrs M. Louvet and Mrs G. Bada for their helpful technical assistance.

\section{References}

Bogdan, K. G. \& J. J. Gilbert, 1982. The effects of posterolateral spine length and body length on feeding rate in the rotifer, Brachionus calyciforus. Hydrobiologia 89: 263-268.

Carlberg, G. E., K. Martinsen, A. Gjessing, E. Grande, M. Källquist \& J. U. Skare, 1986. Influence of aquatic humus on the bioavailability of chlorinated micropollutants in Atlantic Salmon. Arch. Envir. Contam. Toxicol. 15: 543-548.

Clayton, J. R., P. P. Spyros \& N. F. Breitner, 1977. Polychlorinated biphenyls in coastal marine zooplankton: bioaccumulation by equilibrium partitioning. Envir. Sci. Technol. 11: 676-681.

Delbeke, K., C. Joiris \& M. Bossicart, 1990. Organochlorines in Different Fractions of Sediments and in Different Planktonic Compartments of the Continental Shelf and the Scheldt Estuary. Envir. Pollut. 66: 325-349.

Descy, J. P., 1987. Phytoplankton composition and dynamics in the river Meuse (Belgium). Arch. Hydrobiol., suppl. 78, 2 (Algological studies 47): 225-245.

Descy, J. P. \& V. Gosselain, 1994. Development and ecological importance of phytoplankton in a large lowland river (River Meuse, Belgium). Hydrobiologia 289: 139-155.

Gosselain, V., J. P. Descy \& E. Everbecq, 1994. The phytoplankton of the River Meuse, Belgium: seasonal dynamics (year 1992) and the possible incidence of zooplankton grazing. Hydrobiologia 239: 179-191.

Haney, J. F., M. Brauer \& G. Nürnberg, 1986. Feeding and egestion rates of individual zooplankton using Cerenkov counting. Hydrobiologia 141 (Dev. Hydrobiol. 36): 165-174.

Henry, V., J. C. Bussers, J. M. Bouquegneau \& J. P. Thomé, 1989 Heavy metal and PCB contamination of Bryozoan colonies in the River Meuse (Belgium). Hydrobiologia 202: 147-152.

Hiraizumi, Y., M. Takahashi \& H. Nishimura, 1979. Adsorption of Polychlorinated Biphenyl onto Sea Bed Sediment, Marine Plankton, and other Adsorbing Agents. Envir. Sci. Technol. 13: 580-584.

Joiris, C. \& W. Overloop, 1991. PCBs and organochlorine pesticides in phytoplankton and zooplankton in the Indian sector of the southern Ocean. Antarctic Science 3: 371-377.
Jota, M.-A. T. \& J. Hassett, 1991. Effects of environmental variables on biding of a PCB congener by dissolved humic substances. Envir. Toxicol. Chem. 10:483-491.

Liemeroth, N., 1980. Respiration of different stages of juvenile Brachionus calyciflorus. Hydrobiologia 73 (Dev. Hydrobiol. 1): 195-197.

Linko, R. R., P. Rantamaki, K. Rainio \& K. Urpo, 1979. Polychlorinated Biphenyls in Plankton from the Turku Archipelago. Bull. envir. Toxicol. 23: 152-154.

Marneffe, Y. \& J. P. Thomé, 1991. Modalités et voies de transfert des micropolluants (PCB) dans le plancton de l'écosystème mosan. in $\mathrm{P}$. Vernet (ed.), Troisième conférence internationale des limnologues d'expression française. Hommage à F.-A. Forel: 79-82.

Marneffe, Y., J. P. Descy \& J. P. Thomé. Impact of industrial sewage discharges on zooplanktonic populations in the river Meuse. Hydrobiologia, in press.

Nielsen, M. V.\& Y. Oisen, 1989. The dependence of the assimilation efficiency in Daphnia magna on the ${ }^{14} \mathrm{C}$-labeling period of the food alga Scenedesmus acutus. Limnol. Oceanogr. 34: 13111315.

Pilarska, J., 1977. Eco-physiological studies on Brachionus rubens Ehrbg (Rotatoria).IIl Energy balances. Pol. Arch. Hydrobiol. 24: 343-354.

Risebrough, R. W., V. Vreeland, G. R. Harvey, H. P. Milkas \& G. M. Carmignani, 1972. PCB Residues in Atlantic Zooplankton. Bull. envir. Contam. Toxicol. Technol. 8: 345-355.

Sanders, G., K. C. Jones \& J. Hamilton-Taylor, 1992. Historical Inputs of Polychlorinated Biphenyls and Other Organochlorines to a Dated Lacustrine Sediment Core in Rural England. Envir. Sci. Technol. 26: 1815-1821.

Schlösser, U. G., 1982. Sommlung von algen Kulturen (origin and function of the culture collection). Bes. Deutsch. Bot. Ges. 95: 181-276.

Scura, E. D. \& G. H. Theilacker, 1977. Transfer of the Chlorinated Hydrocarbon PCB in a Laboratory Marine Food Chain. Mar. Biol. 40: 317-325

Starkweather, P. L.\& J. J. Gilbert, 1977. Radiotracer determination of feeding in Brachionus calyciftorus: the importance of gut passage times. Arch. Hydrobiol. Beih. 8: 261-263.

Taylor, W. D., J. H. Carey, D. R. S. Lean \& D. J. McQueen, 1991. Organochlorine concentrations in the plankton of lakes in southern Ontario and their relationship to plankton. Can. J. Fish. aquat. Sci. 10: 1960-1966.

Thomé, J. P., M. H. Debouge \& M. Louvet, 1987. Carnivorous Insects as Bioindicators of Environmental Contamination: Organochlorine Insecticide Residues Related to Insect Distribution in Terrestrial Ecosystems. Int. J. Envir. Anal. Chem. 30: 219-232.

Thomé, J. P. \& Y. Vandaele, 1987. PCB trace enrichment from contaminated natural water at the sub ppt level on $\mathrm{C} 18$ microcartridges, Int. J. envir. Anal. Chem. 29: 95-103.

Thomé, J. P., I. Thys, I. Patry \& N. Weltrawski. Chemical affinity of chitosan derivation for PCBs in natural freshwaters: comparison of the sorption efficiency on chitosan and bioconcentration by Daphnia magna. Chitin World Ed. by Z. S. Karnick, N. N. Brzeski, P. J. Bykowski \& A. Wojtasz-Pajok. Verlag für neue Wissenschaft. $800 \mathrm{pp}$. 